\title{
Animations Are Dynamic, Effective Tools For Science Teaching: If You Just Follow The Rules!
}

Danton H. O’Day, University of Toronto at Mississauga, Canada

\begin{abstract}
Textbook companies are increasingly including larger numbers of animations as complementary resources for students and teachers. Are all animations useful as teaching tools? The answer is no. Animations can be useful for communicating dynamic events and processes but only when specific rules are followed. The authors review the important components of effective animations and their extensive, original research on the value of animations in learning and long-term memory retention. When the rules are applied, students can learn complex material more easily and retain more of what they have learned in short and long term memory than they can by viewing static textbook figures. Our results also indicate that learning from animations and graphics differs between males and females. Insight gained from student feedback is highlighted with some final comments on future research.
\end{abstract}

Keywords: Teaching animations versus static graphics; types of learning; short and long term memory; gender

\section{INTRODUCTION}

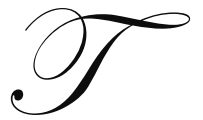

extbook companies are increasing the availability of instructional media to complement their textbooks. Thus we've seen the development of websites where instructors can access supplementary course content ranging from figures to PowerPoint slide shows to animations and fully-fledged interactive exercises. One area of extremely rapid development is in the area of short instructional animations. In support of the use of animations in teaching is an extensive literature that covers many different disciplines. These studies have shown that animations can be more effective than textbook figures (Pollock et al. 2002; Nicholls and Merkel 1996). It seems reasonable that dynamic events would benefit by being represented in a dynamic way (Tversky and Morrison 2002).

The goal of this review is to show, using biological examples, how animations can be used as effective teaching and learning tools. Our past and current research will show that, when appropriate rules are followed, short term learning and long-term memory retention is enhanced through the use of animations. We then review some new research to that provided insight into the types of learning that are most enhanced through the use of animations versus static graphics. This work also revealed some gender-based differences. Finally we summarize some student comments and where we see future research should be directed.

\section{THE ATTRIBUTES OF EFFECTIVE ANIMATIONS}

The cognitive load theory is based upon the concept that there is a limited amount of working memory. If animations use visual and auditory channels effectively, working memory is increased (Mayer et al. 2001; Sweller 1994; Mayer and Anderson 1992). Similarly, overloading the learner with extraneous or confusing material in an animation can inhibit short and long-term memory retention. Thus many of the attributes of an effective teaching animation revolve around this issue. Table one summarizes the fundamental components that should be included in a meaningful instructional animation. There are unlimited ways to lose a student's attention. Discussing or lecturing on material that is beyond their comprehension is one of these. It follows then that this is also true for animations. 
As reflected by the "apprehension principle" the material presented to students must be appropriate to the topic and to their educational level. The content of an animation must be appropriate for a learner to be able to understand it. Animations with too much extraneous detail can overwhelm students reducing their level of comprehension (Tversky and Morrison 2002, Table 1). Focus is important: animations are not effective if they have too much information (Tversky and Morrison 2002; "coherence effect", Mayer, 2003; Table 1). Terminology is critical and specific to each subject area but too much terminology without clarity can lead to problems with comprehension and learning. Animations provide an effective way to link specific words or topic-specific terminology to components, structures or events. Mayer (2003) has shown that effective learning from animations occurs when printed words or terms are placed adjacent to corresponding pictures ("spatial contiguity effect"; Table 1). Learning is further enhanced when words or terms are spoken at the time they appear ("multimedia effect"; Table 1). An informal spoken narrative has been shown by numerous authors to reinforce learning (Lowe, 2003; Mayer and Anderson 1992; Sweller, 1994; "personalization effect", Mayer, 2003; Table 1). Just as importantly, students learn how to say critical terms correctly (O’Day, 2008). Visual representations of change can also assist students in the learning process (Wilson-Pauwels, 1997; Table 1).

Interactivity may be simple (e.g., stop, start, rewind and replay an animation) or complex (e.g., answering questions correctly before progressing). Various studies support the concept that interactivity reinforces the learning process (e.g., Tversky and Morrison, 2002; Table 1). True interactivity engages the student, encouraging them to put the new material into context with previously learned information and to formulate new ideas about that material (Tversky and Morrison, 2002).

Table 1: Essential components of an effective teaching animations

\begin{tabular}{|c|c|c|}
\hline Essential Component & Terminology/Meaning & References \\
\hline Stage-appropriate content & $\begin{array}{l}\text { "Apprehension principle" } \\
\text { The material must not be too } \\
\text { difficult or complex }\end{array}$ & Tversky \& Morrison, 2002 \\
\hline $\begin{array}{l}\text { Absence of extraneous } \\
\text { content }\end{array}$ & $\begin{array}{l}\text { "Coherence effect" } \\
\text { increased irrelevant content } \\
\text { means decreased retention }\end{array}$ & Mayer, 2003 \\
\hline $\begin{array}{l}\text { Text is adjacent } \\
\text { to relevant image }\end{array}$ & $\begin{array}{l}\text { "Spatial contiguity effect" } \\
\text { Relationship between items } \\
\text { reinforces learning }\end{array}$ & Mayer, 2003 \\
\hline Term spoken as it appears & $\begin{array}{l}\text { "Multimedia effect" } \\
\text { Reinforces association between } \\
\text { term and structure/event }\end{array}$ & Mayer, 2003 \\
\hline Conversational narration & $\begin{array}{l}\text { "Personalization effect" } \\
\text { Non-pedantic, sociable } \\
\text { narrative encourages learning }\end{array}$ & $\begin{array}{l}\text { Mayer, 2003; Sweller, } \\
\text { 1994; Lowe, } 2003\end{array}$ \\
\hline Student control & $\begin{array}{l}\text { Interactivity } \\
\text { Allows learning at personal rate; } \\
\text { ranges from start/stop/rewind } \\
\text { to full interactivity }\end{array}$ & Tversky \& Morrison, 2002 \\
\hline Visual cues reflect change & $\begin{array}{l}\text { Visual Cues } \\
\text { Changes in color/sShape } \\
\text { show an event has occurred }\end{array}$ & Wilson-Pauwels, 1997 \\
\hline $\begin{array}{l}\text { Directing attention to } \\
\text { specific items }\end{array}$ & $\begin{array}{l}\text { Attention Cueing } \\
\text { Indicating salient items } \\
\text { ensures they are noticed }\end{array}$ & De Koning et al, 2009 \\
\hline (after O’Day, 2008) & & \\
\hline
\end{tabular}




\section{RESEARCH DATA ON THE VALUE OF ANIMATIONS IN BIOLOGY}

While it is generally agreed that animations are valuable aids for teaching dynamic events, the specific research that has been done on the value of animations for teaching the life sciences is limited. In a small study, Stith (2004) showed that students who viewed an animation obtained significantly higher test scores than those who only saw static graphics of the event. McClean et al. (2005) carried out a more comprehensive and controlled experiment again showing that students who viewed an animation obtained significantly higher test scores than the group that didn't. O'Day (2006) did a larger study allowing statistical comparison to be carried out. In keeping with the previous studies, the students who viewed the animation scored better on a subsequent test than those who viewed a graphic with an equivalent legend but only after sufficient time was provided (Figure 1).

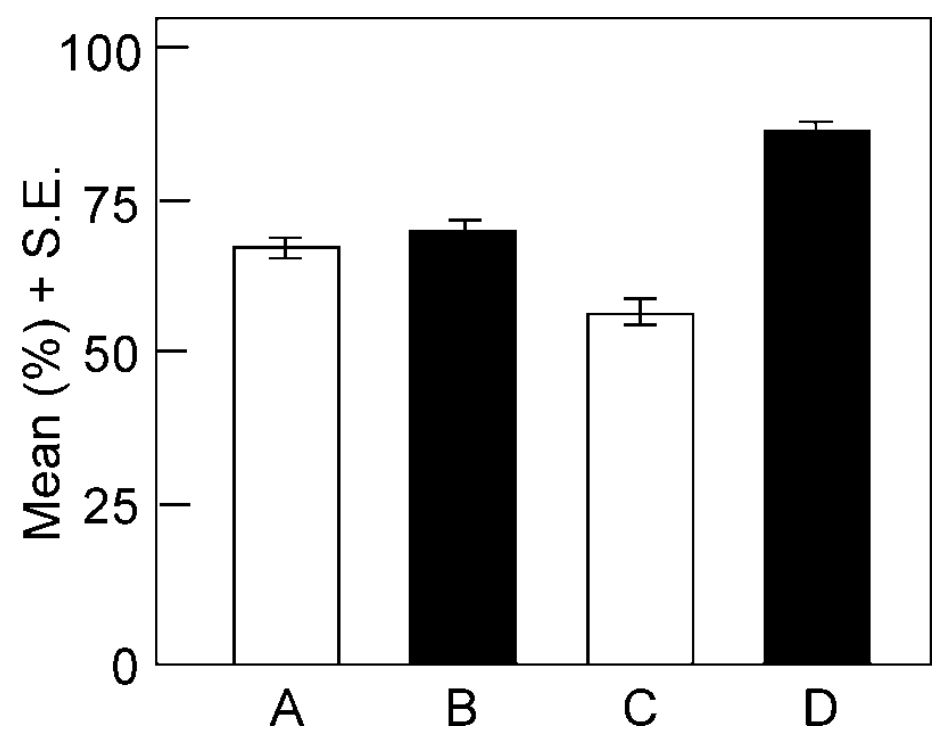

Figure 1

A bar graph showing the results of the four groups on questions based upon viewing the animation or static graphic. The mean and standard error for each group are shown. As detailed in the results, ANOVA one-way analysis of variance revealed that the results for group $\mathrm{D}$ were significantly $(\mathrm{P}<0.05)$ different from groups $\mathrm{A}, \mathrm{B}$ and $\mathrm{C}$ while group $\mathrm{C}$ was significantly $(\mathrm{P}<0.05)$ different from groups A and B. (after O'Day, 2006)

A follow-up study with over 200 students supported those results (O'Day, 2007). The second part of that study provided data on the value of animations in long-term memory retention (Figure 2). Three different unnarrated animations were used and for all of them, the students who viewed the animations lacking the narration scored significantly higher on the retention tests than those who viewed the equivalent graphic even when a legend was present (O’Day, 2007). Surprisingly, for two of the animations the students retained 87-93\% of the information they originally remembered. That was the first study on the value of animations in long-term memory retention and provides strong evidence that students retain information learned from animations longer than from graphics.

Narration is considered to be an important attribute of educational animations (Mayer, 2003; Lowe, 2003; Sweller, 1994). Based on studies in other disciplines showing the value of a proper narrative, the expected result was that the three separate cases of un-narrated animations in this study would all lead to lower mean marks as compared to a previous equivalent study with a narrated animation (87.5\%; O’Day, 2005). In keeping with this, the mean initial retention average (76.9\%) for the three un-narrated animations used in this study was about $10 \%$ less than observed previously supporting the view that narration is a valuable, if not essential, component in biological animations. However, future research which focuses specifically on narrated versus un-narrated animations compared to graphics with and without an equivalent legend would allow us to make stronger conclusions in this matter. 


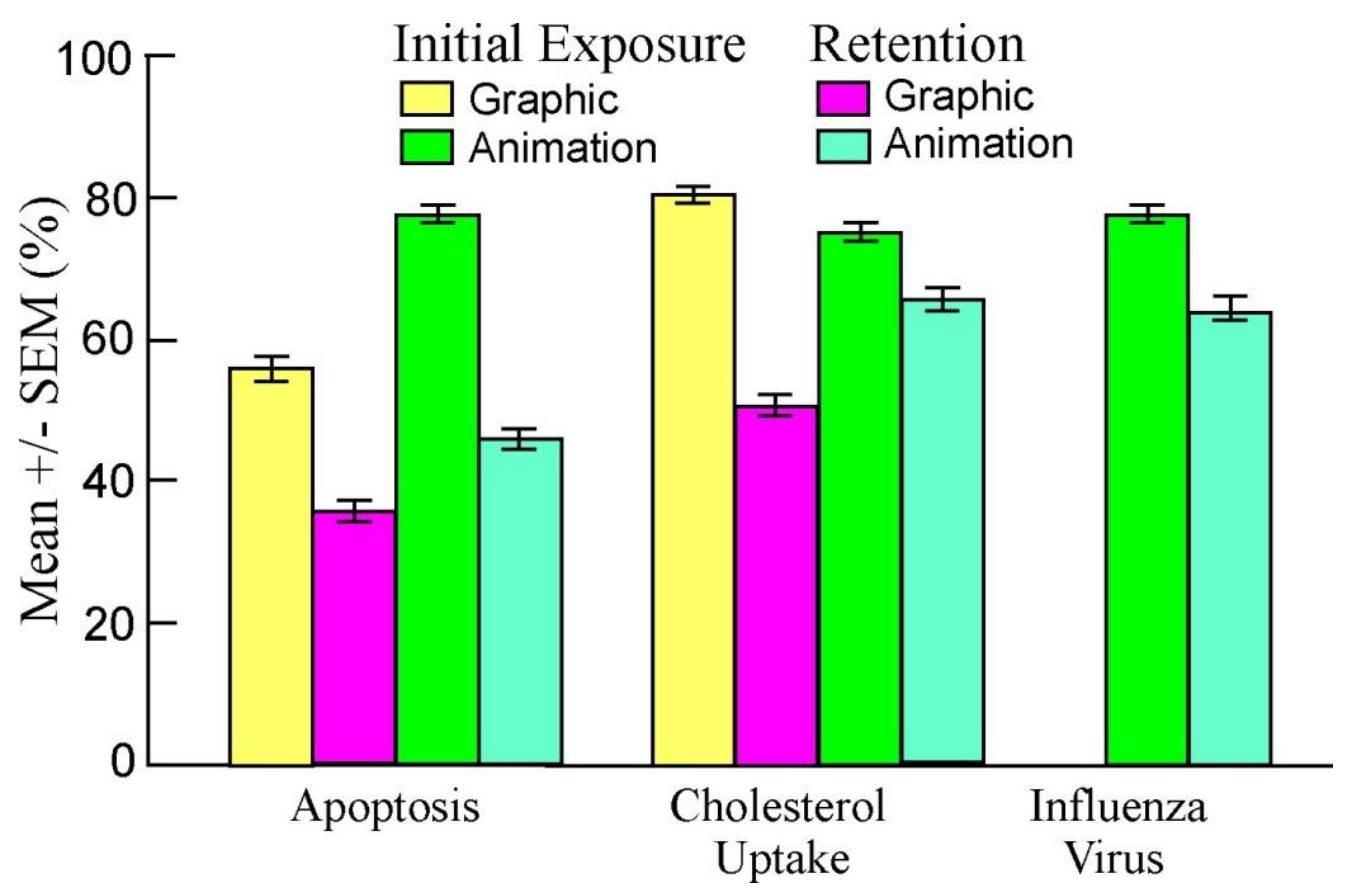

Figure 2

Questionnaire results for initial exposure and retention analysis. The mean and standard error of the mean ( \pm SEM) grades for the results were calculated for the four groups (Initial exposure: animation and graphic; Retention: animation and graphic) for two cases (Apoptosis and Cholesterol Uptake analyses) and for the Initial exposure and Retention: animation only for the third case

(Influenza Virus analysis). (After O’Day, 2007)

\section{ONGOING RESEARCH: DIFFERENT RESULTS BETWEEN MALE AND FEMALE STUDENTS}

In his study, Stith (2004) suggested that questions involving rote memory (definition) did not benefit from the animation but those involving dynamic processes ("order or location of events") did. The evaluation of specific questions in one of my studies partly supported this idea (O'Day, 2007). However in-depth evaluation of those questions versus the others as to difficulty, question type or complexity did not yield any insight into a potential cause.

There are few articles on gender-based differences in the value of animations. On the whole research supports the idea that, on a populational basis, females will benefit less from scientific animations than males. There are two main reasons for this conclusion (Sáinz \& López-Sáez, 2010; Sanchez \& Wiley, 2010). First, amongst females there is a comparative lack of interest in the areas of science and technology. Second, females, as a group, show weaker spatial abilities. Several studies show that spatial abilities are directly related to the use and benefit from animations (see, Cohen \& Hegarty, 2007). However, a recent earth science study suggests that females do benefit from animations that detail spatial events and this can overcome sex-based differences (Sanchez \& Wiley, 2010). So it is important not to have preconceived ideas when attempting to understand gender-based differences in learning but to be sensitive that at times these may come into play.

In our most recent study, we considered Bloom's (1984) "Taxonomy of Educational Objectives" in the design of a questionnaire with type-specific questions to determine if that could provide more critical insight into when animations should be employed over static graphics (O'Day and Catalano, 2010). In this study, we compared the results of males versus females on the specific question types after the students viewed an animation, a graphic or both the animation and the graphic. We assessed their performance on a set of 15 questions that fell into three different categories (i.e., 5 questions/category): retention of facts, sequence of events and application (problem solving, reasoning). The results revealed that significant differences were only observed between males and females 
for the application questions. The data showed that animations are more beneficial for males than graphics alone (Figure 3). Females displayed the same retention regardless of presentation type. This is an interesting finding as it indicates that the mode of presentation should be catered to sex for optimal long term retention of information.

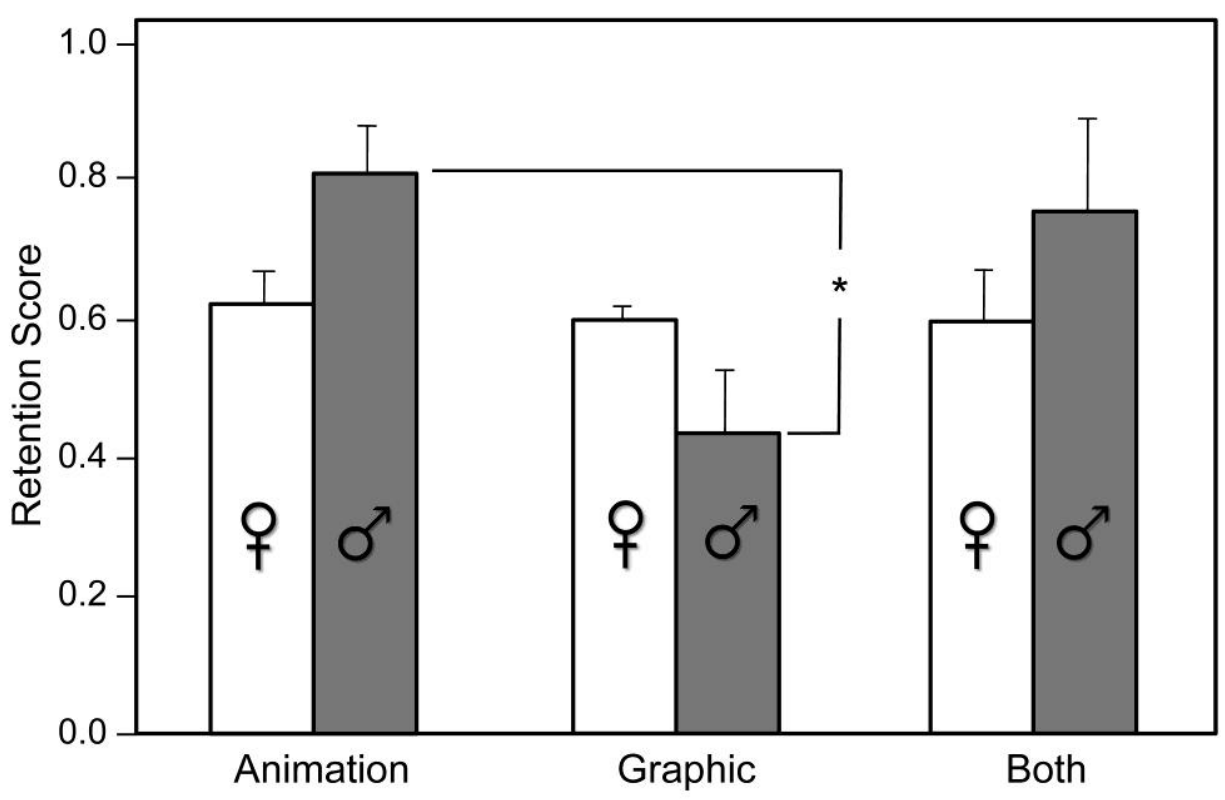

Figure 3

Retention results of questionnaire for both males and females for type 3 questions. Students were either given an animation for 15 minutes, shown a graphic of the same material for 15 minutes, or given the animation for 7.5 minutes followed by the graphic for

7.5 minutes. Students then completed a questionnaire immediately after viewing the material and the same questionnaire two weeks later. Retention test scores were then divided by initial exposure test scores for each student. The mean and standard error of the mean were calculated for each group. Males that viewed the animation only displayed significantly better retention than males that viewed the graphic only. ( ${ }^{*} \mathrm{P}<0.05$; After O’Day \& Catalano, 2010).

\section{ANIMATIONS: STUDENT COMMENTS}

Student feedback is useful in assessing the pedagogical value of animations and graphics (O’Day, 2006, 2007, 2008). Students enjoy animations as a change from reading text and attempting to interpret graphics. Biology is a visual subject often involving complex sequences of events. Animations provide one way of communicating such complex sequences clearly and efficiently. To paraphrase the idea expressed by several students, "after viewing the animation, reading the textbook becomes easier and more enlightening".

Any effective teacher can tell you that different students learn in different ways. Students echo this critical point. In the study by O'Day (2006), while the majority of cell biology students preferred an animation over equivalent static graphics with text, they also overwhelmingly stated that each has its place in the learning process. While the animation was valuable for showing the complete dynamic process, many students said that static graphics allowed them to focus on specific details. More importantly many expressed concern that they don't always have access to multimedia players while printed material is easily accessible at all times. As access to technology continues to change with the continued development and accessibility of hand-held multimedia devices, this issue will likely be less of a concern in the future but today it remains an issue to consider.

There have been suggestions in the literature that students are passive viewers when watching teaching animations (Hegarty et al, 2004). However student comments indicate that when they view educational animations they are not doing so passively but many are actively thinking about what they are viewing (O’Day, 2006, 2010). In 
short, there is no data proving that students who view educational animations are viewing them passively as they would a cartoon or other non-educational animation.

Table 2: Some Issues to Consider in Future Studies

\begin{tabular}{ll}
\hline Issue & Comments/Questions \\
\hline Length of animation & $\begin{array}{l}\text { Are shorter (1-3min) animations better than longer ones? } \\
\text { What relationship exists between length and retention? }\end{array}$ \\
& $\begin{array}{l}\text { Would other studies have obtained (e.g., Lowe, 2003) } \\
\text { different results with longer/sufficient time for viewing? }\end{array}$ \\
Interactivity & $\begin{array}{l}\text { What level of interactivity, if any, is required for } \\
\text { effectiveness? Clearly interactivity enhances retention. }\end{array}$ \\
& $\begin{array}{l}\text { Do teaching animations involve active or passive learning? } \\
\text { Classroom Discussion } \\
\text { (Interactivity) }\end{array}$ \\
$\begin{array}{l}\text { What is the value of in-class discussion in assisting } \\
\text { students understand the content of animations (e.g., } \\
\text { McClean et al, 2005)? }\end{array}$ \\
$\begin{array}{l}\text { There is a need to develop questionnaires that provide } \\
\text { deeper insight into exactly what aspects of learning are } \\
\text { enhanced through the use of animations. }\end{array}$ \\
$\begin{array}{l}\text { Few studies exist using freshman/sophomore student in } \\
\text { college/university; none exist in life sciences on value to } \\
\text { high school students }\end{array}$
\end{tabular}

(after O’Day, 2008)

\section{What Next?}

The goal of our research has been to understand the essential parameters that make animations an effective teaching and learning tool. While the fundamental parameters of effective teaching animations have been detailed above, many aspects remain to be studied especially as they apply to students at different levels (Table 2; O'Day, 2008). More work needs to be done on the significance of animation length and of appropriate viewing time (O'Day, 2006, 2007). McClean et al (2005) complemented their animations with in-class discussions, an area that also needs further detailed analysis. As mentioned above, some post-viewing comments by students indicate they are not viewing animations passively (O'Day, 2006). How much additional interactivity is needed for animations to be even more effective teaching and learning tools? Is the use of sound effects as effective as the use of color and shape to indicate a change has occurred in an event or item (Wilson-Pauwels, 1997)? Does background music enhance or hinder learning? To date, most studies have focused on college/university students. It is important to determine the value of animations for teaching high school students.

\section{ACKNOWLEDGEMENT}

This work was supported in part by a grant from the Information Technology Courseware Development Fund at the University of Toronto.

\section{AUTHOR INFORMATION}

Danton (Dan) H. O'Day, PhD. Dan O'Day has taught biology at the University of British Columbia, University of Delaware, Lincoln University and the University of Toronto Mississauga, where he currently is a full professor. He has published over 100 refereed articles in the field of cell biology. He also produces animations using PowerPoint and Camtasia Studio to augment his teaching and for his teaching research. He has published a several refereed articles on the value of animations for teaching science and presented this work at many international meetings. He has also published numerous student guides to help college students succeed. 


\section{REFERENCES}

1. Bloom, B.S., 1984. "Taxonomy of Educational Objectives". Allyn \& Bacon, Boston, MA.

2. Cohen, C. A., \& Hegarty, M. (2007). Individual differences in use of external visualizations to perform an internal visualization task. Applied Cognitive Psychology, 21, 701-711.

3. de Koning, B. B., Tabbers, H. K, Rikers, R. M. J. P., \& Paas, F. (2009). Towards a framework for attention cueing in instructional animations: guidelines for research and design. Educational Psychology Reviews 21, 113-140.

4. Heyden, R.J., 2004. Approaches to Cell Biology: Developing Educational Multimedia. Cell Biology Education; 3, 93-98.

5. Lowe, R. K. 2003. Animation and learning: Selective processing of information in dynamic graphics. Learning and Instruction; 13, 157-176.

6. Mayer, R.E. (2003). The promise of multimedia learning: using the same instructional design methods across different media. Learning and Instruction; 13, 125-139.

7. Mayer, R. E., and R. B. Anderson. 1992. The instructive animation: helping students build connections between words and pictures in multimedia learning. Journal of Educational Psychology; 84, 444-452.

8. Mayer, R. E., and J. Jackson. 2005. The case for coherence in scientific explanations: quantitative details can hurt qualitative understanding. Journal of Experimental Psychology: Applied; 11, 13-18.

9. Mayer, R. E., J. Heiser, and S. Lonn. 2001. Cognitive constraints on multimedia learning: when presenting more material results in less understanding. Journal of Educational Psychology; 93, 187-198.

10. McClean, P., C. Johnson, R. Rogers, L. Daniels, J. Reber, B.M. Slator, J. Terpstra and A. White, 2005. Molecular and cellular biology animations: Development and impact on student learning. Cell Biology Education; 4, 169-179.

11. Nicholls, C., and S. Merkel. 1996. The effect of computer animation on students' understanding of microbiology. Journal of Research on Computing in Education; 28, 359- 372.

12. O’Day, D.H., 2006. Animated Cell Biology: A Quick \& Easy Method for Making Effective High-Quality Teaching Animations. CBE: Life Sciences Education 5, 155-163.

13. O'Day, D.H., 2007. The Value of Animations in Biology Teaching: A Study of Short-Term and LongTerm Memory Retention. CBE: Life Sciences Education 6, 217-233. (plus Appendices).

14. O’Day, Danton H., 2008. Using Animations to Teach Biology: Past and Future Research on the Attributes that Underlie Pedagogically Sound Animations. American Biology Teacher 70, 286-290.

15. O'Day, D.H. and A.C. Catalano, 2010. Long term memory retention with scientific animations: A genderbased study. (unpublished data).

16. Pollock, E., P. Chandler, and J. Sweller. 2002. Assimilating complex information. Learning and Instruction; 12, 61-86.

17. Sáinz, M., \& López-Sáez, M. (2010). Gender differences in computer attitudes and the choice of technology-related occupations in a sample of secondary students in Spain. Computers \& Education, 54, 578-587.

18. Sanchez, C. A., \& Wiley, J. (2010). Sex differences in science learning: Closing the gap through animations. Learning and Individual Differences, 20, 271-275.

19. Reimann, P., 2003. Multimedia learning: beyond modality. Learning and Instruction 13: 245-252

20. Sweller, J. 1994. Cognitive load theory, learning difficulty, and instructional design. Learning and Instruction; 4, 295-312.

21. Stith, B.J., 2004. Use of animation in teaching cell biology. Cell Biology Education 3: 181-188.

22. Tversky, B., and J. B. Morrison. 2002. Animation: can it facilitate? International Journal of HumanComputer Studies; 57, 247-262.

23. Wilson-Pauwels, L. 1997. Bringing it into focus: visual cues and their role in directing attention. Journal of Biomedical Communication; 24, 12-16. 


\section{NOTES}

